\title{
PRINSIP KERJA SAMA PADA RAGAM BAHASA FORMAL DALAM DIALOG ROSI DI KOMPAS TV
}

\author{
Rudi $^{1}$, Gigit Mujianto ${ }^{2}$ \\ Universitas Muhammadiyah Malang \\ Email :rudikisara15@gmail.com ${ }^{1}$, gigit@umm.ac.id ${ }^{2}$
}

\begin{abstract}
Abstrak: Pemakaian prinsip kerja sama pada suatu aktivitas tuturan memberikan pengaruh positif. Penelitian ini bertujuan untuk mendeskripsikan: (1) jenis-jenis pemakaian prinsip kerja sama pada ragam bahasa formal dalam dialog Rosi di Kompas TV, (2) ciri-ciri linguistik ragam bahasa formal dalam dialog Rosi di Kompas TV. Jenis penelitian adalah kualitatif dengan pendekatan deskriptif. Sumber data penelitian adalah interaksi pewara dengan narasumber dalam dialog Rosi di kanal youtube Kompas TV. Adapun data berupa kalimat yang mencerminkan jenis-jenis pemakaian prinsip kerja sama pada ragam bahasa formal dan ciri-ciri linguistik ragam bahasa formal. Prosedur pengumpulan data penelitian dengan teknik observasi. Teknik analisis data menggunakan model Miles dan Huberman dengan mencangkup tahapan reduksi data, penyajian data, dan penarikan kesimpulan. Hasil penelitian menunjukkan: (1) jenis-jenis pemakaian prinsip kerja sama pada ragam bahasa formal memenuhi syarat maksim kuantitas, maksim kualitas, dan maksim relevansi, (2) ciri-ciri linguistik ragam bahasa formal meliputi penggunaan gramatikal yang eksplisit dan konsisten, penggunaan imbuhan yang lengkap, penggunaan kata ganti resmi, dan penggunaan kata baku dan menghindari unsur kedaerahan. Dapat disimpulkan bahwa pemakaian prinsip kerja sama pada ragam bahasa formal sangat esensial untuk mewujudkan komunikasi yang baik, dan melestarikan bahasa formal yang sesuai dengan kaidah-kaidah dalam bahasa Indonesia.
\end{abstract}

Kata Kunci: maksim, prinsip kerja sama, ragam bahasa formal.

\section{COOPERATION PRINCIPLES IN FORMAL LANGUAGE IN THE DIALOGUE OF ROSI ON KOMPAS TV}

\begin{abstract}
The use of the cooperative principle in a speech activity has a positive influence This study aims to describe: (1) the types of use of the principle of cooperation in various formal languages in Rosi dialogue on the Kompas TV, (2) the linguistic characteristics of the variety of formal languages in Rosi dialogue on the Kompas TV. This type of research is qualitative with a descriptive approach. The source of the research data is the interviewer's interaction with the resource person in Rosi dialogue on the Kompas TV youtube channel. The data are in the form of sentences that reflect the types of use of the cooperation principle in various formal languages and the linguistic features of various formal languages. Research data collection procedures using observation techniques. The data analysis technique uses the Miles and Huberman model, which includes data reduction, data presentation, and conclusion drawing. The results showed: (1) the types of use of the principle of cooperation in various formal languages fulfill the requirements of the maxim of quantity, the maxim of quality, and maxim of relevance, (2) The linguistic characteristics of formal language varieties include explicit and consistent grammatical use, complete use of affixes, use of official pronouns, and use of standard words and avoid regional elements. Can be concluded that the use of the principle of cooperation in a variety of formal
\end{abstract}

BASASTRA Jurnal Bahasa, Sastra, dan Pengajarannya

Volume 9 Nomor 2, Oktober 2021, P-ISSN 2302-6405, E-ISSN 2714-9765 
languages is essential for realizing good communication, and preserving formal language in accordance with the rules of the Indonesian language.

Keywords: maxims, the principle of cooperation, variety of formal languages.

\section{PENDAHULUAN}

Bahasa menduduki peranan yang sangat esensial dalam hal ihwal kehidupan. Dengan adanya bahasa, mendukung terhadap fitrah manusia sebagai makhluk sosial. Artinya, manusia mampu berinteraksi secara sempurna dengan manusia lain melalui media bahasa. Hal tersebut dipertegas Prasasti dan Mujianto (2020: 147), menuturkan bahwa manusia menjadikan bahasa sebagai sarana berkomunikasi dan bersosialisasi dengan masyarakat lainnya. Senada dengan Prasasti, Mujianto, dan Mujiyati (2017: 115) juga mengatakan bahasa sebagai alat komunikasi manusia dalam konteks sosial yang diwujudkan melalui bunyi. Berdasarkan hal tersebut, mengisyaratkan bahwa bahasa dengan masyarakat memiliki jalinan yang kuat dalam membangun peradaban ke arah yang baik. Hal ini dapat terjadi karena melalui bahasa, masyarakat dapat mempelajari dan menyampaikan berbagai disiplin ilmu lainnya.

Oleh karena itu, kemampuan bertutur pada abad-21 sangat penting dimiliki seseorang, agar mampu menyampaikan informasi secara tersistematis. Pada kegiatan tuturan, terbentuk sebuah percakapan. Percakapan lazimnya dilakukan oleh dua orang atau lebih dalam melakukan suatu komunikasi pada peristiwa tertentu, agar makna tuturan dapat dipahami (Rudi \& Mujianto, 2021: 69). Di dalam peristiwa tutur tersebut, penutur menginginkan agar informasi yang disampaikan dapat dimaknai dengan baik oleh mitra tutur. Maka dari itu, penutur menggunakan berbagai strategi, salah satunya dengan pemakaian prinsip kerja sama.

Pemakaian prinsip kerja sama pada suatu aktivitas tuturan memberikan pengaruh positif. Menurut Rahardi (2005: 52), agar pesan dapat terealisasi dengan baik pada kegiatan berkomunikasi, maka peserta tutur harus memperhatikan prinsip kerja sama yang dikemukan oleh Paul Grice. Lebih lanjut, Paul Grice pada "Logic and Conversation" yang terhimpun dalam bukunya yang berjudul "Studies in the Way of Words", mengkategorikan prinsip kerja sama menjadi, maksim kuantitas, maksim kualitas, maksim relevansi, dan maksim pelaksanaan (Grice, 1989: 31). Keempat maksim tersebut penting dihadirkan dalam kegiatan berkomunikasi, untuk menghindari terjadinya konflik yang disebabkan oleh kesalahpahaman antara penutur dengan mitra tutur.

Adapun fenomena pemakaian prinsip kerja sama juga tampak pada situasi tuturan yang bersifat formal, salah satunya pada dialog Rosi. Di dalam dialog tersebut, 
menggambarkan adanya penggunaan PK pada ragam bahasa formal yang dilakukan oleh peserta tutur. Hal ini dapat terjadi, karena bahasa sebagai produk sosial dan kebudayaan (Sumarsono, 2017: 20). Faktor sosial penutur, yang mencakup latar belakang ekonomi, gender, umur, dan sebagainya memengaruhi terhadap pemakaian suatu bahasa (Suhendar, 2016: 54). Oleh sebab itu, pada kegiatan tuturan muncul variasi (ragam) bahasa yang digunakan penutur dalam mengungkapkan perasaannya. Artinya, setiap bahasa yang digunakan penutur dalam peristiwa tertentu mencerminkan kegiatan perilaku sosial dari penutur. Dalam hal ini, penelitian difokuskan pada ragam bahasa formal.

Ragam bahasa formal merupakan variasi bahasa yang digunakan dalam situasi resmi, seperti pada kegiatan rapat dinas, pembelajaran di kelas, dan sebagainya. Hal ini sesuai yang dikemukakan Kushartanti (2005: 50), ragam bahasa formal digunakan pada situasi resmi serta ditandai dengan pemakaian kata dan kalimat yang lengkap, akurat sesuai dengan kaidah bahasa Indonesia. Latar belakang sosial peserta tutur sangat penting dalam menentukan terhadap pemakaian ragam bahasa formal (Ula et al., 2020: 51). Penggunaan ragam bahasa formal memberikan impak terhadap status sosial dan juga sering digunakan untuk menegaskan posisi kekuasaan atau martabat penutur (Herisetyanti et al., 2019). Dengan demikian, ragam bahasa formal yang digunakan dalam kegiatan komunikasi mencerminkan intelektualitas penuturnya.

Penelitian terhadap prinsip kerja sama sudah pernah dilakukan oleh beberapa penelitian terdahulu. Pertama, Wijining (2018) dengan judul "Penerapan prinsip kerja sama Grice dalam percakapan di persidangan agama Surabaya". Fokus penelitian adalah untuk mendeskripsikan penerapan dan pelanggaran prinsip kerja sama Grice yang terjadi dalam percakapan di persidangan agama Surabaya. Hasil penelitian ini menunjukkan dua kesimpulan. Pertama, penerapan prinsip kerja sama Grice ditemukan dalam bentuk maksim kuantitas, maksim kualitas, maksim hubungan dan maksim cara dengan data didominasi dengan maksim kuantitas. Kedua, pelanggaran prinsip kerjasama Grice ditemukan dalam bentuk maksim kuantitas dan maksim hubungan.

Kedua, Sahara (2020) dengan judul "Prinsip Kerja Sama Grice pada Percakapan Film". Penelitian ini memfokuskan pada penerapan prinsip kerja sama Grice. Dengan aspek kajian terhadap pemenuhan prinsip kerja sama Grice, dan pelanggaran prinsip kerja sama Grice. Hasil penelitian menunjukkan bahwa pemakaian prinsip kerja sama terjadi pada tataran prinsip kuantitas, prinsip kualitas, prinsip hubungan, dan prinsip cara. 
Selain itu, pelanggaran dilakukan dengan tidak menerapkan prinsip kerja sama, sehingga komunikasi yang dilakukan tidak efektif.

Penelitian lain mengenai ragam bahasa formal, juga sudah dilakukan oleh peneliti terdahulu. Pertama, oleh Herisetyanti, Suharyati, \& Rejeki (2019) dengan judul "Ragam Bahasa dalam Kompenen Tutur", penelitian ini membahas tentang jenis ragam bahasa dan bentuk komponen tutur dalam setiap penggunaan ragam bahasa tokoh utama. Hasil penelitian menunjukkan pemakaian ragam bahasa mencakup ragam resmi, konsultatif, santai, dan intim. Penggunaan ragam bahasa tersebut dipengaruhi oleh kompen tutur sosial dan dimensi sosial. Pada penelitian ini membahas ragam bahasa formal secara umum dan ciri-ciri linguistik, tetapi belum mendeskripsikan ciri-ciri linguistik ragam bahasa formal secara detail. Adapun objek bahasa yang dijadikan data adalah bahasa Inggris, sementara pada penelitian yang akan dilakukan menggunakan data bahasa Indonesia. Maka dari aspek struktur pola kalimat juga berbeda.

Kedua, oleh Hidayat, Rusminto, \& Widodo (2018) dengan judul "Ragam Bahasa dalam Acara Talk Show Mata Najwa Periode Januari 2017 dan Implikasinya dalam Pembelajaran Bahasa Indonesia di SMA". Penelitian ini memfokuskan terhadap ragam bahasa dalam acara talk show Mata Najwa periode Januari
2017 dan mengetahui implikasinya dalam pembelajaran bahasa Indonesia di SMA. Hasil penelitian menunjukkan pemakaian ragam bahasa terjadi berdasarkan, (1) penutur pada ragam dialek, kolokial, dan jargon, (2) pemakaian pada ragam jurnalistik, (3) keformalan pada ragam formal, usaha, dan santai, (4) sarana pada ragam lisan. Adapun implikaturnya terhadap pembelajaran bahasa Indonesia kelas $\mathrm{X}$ pada kompetensi dasar 3.13 dan 4.14. Pada penelitian ini menguraikan terkait ragam bahasa formal berdasarkan ciri linguistik aspek kelengkapan imbuhan. Berdasarkan penelitian terdahulu yang diuraikan di atas, belum menunjukkan adanya kajian yang mengaitkan pemakaian prinsip kerja sama dengan ragam bahasa formal. Selain itu, uraian terkait ciri-ciri linguistik ragam bahasa formal belum diuraikan secara lengkap. Oleh karena itu, penelitian akan mendiskusikan tentang (1) jenis-jenis pemakaian prinsip kerja sama pada ragam bahasa formal dalam dialog Rosi di Kompas $\mathrm{TV}$, dan (2) ciri-ciri linguistik ragam bahasa formal dalam dialog Rosi di Kompas TV. Maka dari itu, penelitian ini secara keseluruhan tidak hanya menguraikan aspek fungsional bahasa (prinsip kerja sama), melainkan juga membahas variasi bahasa (ragam bahasa formal).

\section{METODE}

Jenis penelitian ini adalah kualitatif dengan teknik deskriptif,

BASASTRA Jurnal Bahasa, Sastra, dan Pengajarannya

Volume 9 Nomor 2, Oktober 2021, P-ISSN 2302-6405, E-ISSN 2714-9765 
untuk menggambarkan hasil pengamatan terhadap jenis-jenis pemakaian prinsip kerja sama pada ragam bahasa formal dan ciri-ciri linguistik ragam bahasa formal, dengan cara deskripsi dalam bentuk kata-kata.

Sumber data penelitian adalah interaksi pewara dengan narasumber dalam dialog Rosi di kanal youtube Kompas TV. Pada dialog Rosi terdapat beberapa tayangan video, tetapi dalam penelitian ini memfokuskan pada dua video, yaitu sebagai berikut. Pertama, video dengan topik "Ada Apa dengan Risma?” diunggah pada 2 Juli 2020. Kedua, video dengan topik "Corona, Ujian Indonesia Maju” diunggah pada 14 Agustus 2020. Adapun data dalam penelitian ini berupa kalimat yang mencerminkan tujuan penelitian.

Prosedur pengumpulan data penelitian dengan cara observasi pada video dialog Rosi di kanal youtube Kompas TV, kemudian data yang diperoleh dikelompokkan untuk dianalisis. Dalam proses analisis data dilakukan transkrip rekaman. Teknik analisis data menggunakan model Miles dan Huberman dengan mencangkup tiga alur, yaitu reduksi data, penyajian data, dan penarikan kesimpulan (Anggito \& Setiawan, 2018: 243). Pertama, peneliti mengelompokkan data yang sudah terkumpul sesuai dengan topik dan fokus kajian penelitian, agar dapat ditarik suatu kesimpulan. Kedua, setelah memperoleh data melalui proses reduksi, peneliti menyajikan data dengan cara teks naratif, sehingga memudahkan dalam menginterpretasi maknanya. Ketiga, langkah yang terakhir peneliti menarik kesimpulan untuk memberikan makna pada data sesuai dengan teori/konsep yang digunakan dalam penelitian.

\section{HASIL DAN PEMBAHASAN}

\section{HASIL}

\section{Jenis-jenis Pemakaian Prinsip Kerja} Sama pada Ragam Bahasa Formal dalam Dialog Rosi di Kompas TV

Tuturan dalam dialog Rosi yang diperoleh dari kanal youtube Kompas $\mathrm{TV}$, ditemukan beberapa pemakaian maksim yang dipatuhi oleh penutur dan mitra tutur. Penggunaan maksim tersebut, meliputi: (1) maksim kuantitas, (2) maksim kualitas, dan (3) maksim relevansi. Hal tersebut dapat dijelaskan sebagai berikut.

\section{Maksim Kuantitas}

Penggunaan maksim kuantitas menuntut peserta tutur untuk memberikan informasi yang informatif, memadai, dan memiliki kesesuaian terhadap apa yang dikehendaki oleh kawan tutur. Dalam hal ini, penggunaan maksim kuantitas dicermikan oleh pewara (Rosi) dan narasumber (Risma) saat melakukan kegiatan interaksi dalam sebuah acara bertajuk ada apa dengan Risma?. Hal 
tersebut dapat dilihat berdasarkan penyataan berikut.

(1) Dialog menit 4;43-4;53

Rosi: “... selamat malam $B u$ Risma."

Risma: "selamat malam Mbak."

Rosi: "apa kabar Bu, sehat?"

Risma: "Baik, alhamdulillah sehat."

Konteks tuturan pada data 1 , yaitu Rosi memberikan sapaan dan menanyakan kabar kepada Risma. Tuturan sapaan yang dilakukan Rosi diwujudkan melalui frasa nomina "selamat malam Bu Risma" berfungsi sebagai penanda waktu (peristiwa tutur) bahwa komunikasi dilakukan pada malam hari, dan sebagai bentuk salam kepada narasumber di awal kegiatan dialog. Tuturan sapaan tersebut juga dipertegas melalui kata Bu, yang menunjukkan rasa hormat kepada perempuan yang lebih tua. Kemudian Risma memberikan respons dengan cara frasa nomina "selamat malam Mbak Rosi”. Kata Mbak pada kalimat tersebut menunjukkan adanya nilai kekerabatan.

Selain itu, Rosi juga menanyakan kabar kepada Risma, dapat dilihat pada kalimat tanya berikut “apa kabar Bu, sehat?”. Tuturan yang dilakukan oleh Rosi mengandung nilai tuturan simpati, karena berusaha untuk memastikan kesehatan Risma. Sehingga tuturan ini menuntut agar Risma memberikan pernyataan perihal kesehatannya yang dipertegas melalui kata apa. Risma menjawab dengan tuturan yang bersifat informatif, dapat dibuktikan pada tuturan "baik, alhamdulillah sehat". Tuturan yang dilakukan oleh Rosi dan Risma tidak berlebihan dan informatif.

Berdasarkan hal tersebut, dapat disimpulkan bahwa tuturan pada data termasuk maksim kuantitas, karena memenuhi syarat, yaitu tuturan bersifat informatif, memadai, dan sesuai dengan konteks dalam tuturan yang dilakukan penutur dan mitra tutur.

\section{Maksim Kualitas}

Pemakaian maksim kualitas dalam kegiatan komunikasi bertujuan agar peserta tutur menyapaikan informasi yang sesuai dengan fakta. Fakta tersebut diperoreh dengan cara memberikan bukti-bukti yang kuat dari hasil riset, pengamatan terhadap pelbagai fenomena yang terjadi, dan lain sebagainya. Oleh karena itu, dengan adanya maksim kualitas dapat memberikan pengaruh terhadap pengurangan informasi yang bersifat hoaks. Dalam hal ini penggunaan maksim kualitas terjadi pada kegiatan komunikasi yang dilakukan oleh Rosi dan Muhajir Efendi pada acara dialog Rosi dengan tajuk Corona, Ujian Indonesia Maju. Hal tersebut dapat dilihat berdasarkan penyataan berikut.

(2) Dialog menit 11;20-12;00

Rosi: "menurut Pak Muhajir apa, apa yang paling ideal buat pejabat publik yang memberikan contoh 
ketidakdisiplinan dalam protokol kesehatan?"

Muhajir Efendi: "kalau di dalam impress sudah diatur, ada teguran lisan, teguran tulis. Kemudian kerja sosial, dan seterusnya. Saya kira yang penting pejabat itu harus dijatuhi sangsi oleh pejabat yang lebih tinggi. sehingga punya kekuatan untuk dipatuhi oleh yang bersangkutan. Tapi saya ... (fonem tidak jelas) tidak boleh ada tembang pilih, karena pejabat kemudian cukup dengan kita Maaf tapi dia ada sanksi yang jelas."

Konteks tuturan pada data 2, yakni Rosi memberikan pertanyaan kepada Muhajir Efendi mengenai sanksi yang sesuai untuk para penjabat yang tidak mematuhi protokol kesehatan. Rosi menyampaikan hal tersebut sesuai dengan fakta di masyarakat, bahwa banyak oknom pemerintah melakukan pelanggaran protokol kesehatan. Padahal saat ini protokol kesehatan sangat penting untuk dilaksanakan disemua kalangan. Tuturan Rosi diwujudkan melalui kalimat tanya berikut "menurut Pak Muhajir apa, apa yang paling ideal buat pejabat publik yang memberikan contoh ketidakdisiplinan dalam protokol kesehatan?". Pada kalimat tersebut menggambarkan bahwa Rosi menginginkan jawaban dari Muhajir Efendi. Oleh karena itu, Muhajir Efendi melaksanakan keinginan Rosi dengan menjawab pertanyaan, yang sesuai dan disertai dengan bukti/data yang kuat. Hal tersebut dapat dilihat pada kalimat "kalau di dalam inpres sudah diatur, ada teguran lisan, terguran tulis. Kemudian kerja sosial, dan seterusnya.". Dengan demikian tuturan tersebut dapat dikategorikan memenuhi maksim kualitas, karena informasi yang disampaikan didukung dengan bukti berupa instruksi presiden (inpres).

\section{Maksim Relevansi}

Penggunaan maksim relevansi bertujuan agar komunikasi yang dilakukan dapat memberikan kontribusi yang sesuai, sehingga komunikasi terjalin secara efektif dan efesien. Seperti pada tuturan yang dilakukan oleh Rosi dan Sakdiyah terdapat pemakaian maksim relevansi. Hal ini dapat dibuktikan pada pernyataan berikut.

(3) Dialog menit 47;32-48;03

Rosi: “didengar kok oleh Pak Menko PMK yang membawa (terjadi keselip lidah), membawahi Kementerian Pendidikan dan Kebudayaan. Sakdiyah terakhir kesempatan untukmu, kira-kira Indonesia tujuh puluh lima tahun usia yang sangat cantik, tujuh puluh lima tahun tetapi juga kita menjadi apa, eee menjadi tidak seperti biasanya. Kira-kira ini kalau mau kamu stand up. Apa materi stand up mu tujuh 
puluh lima tahun Indonesia merdeka? slogannya Indonesia maju di tengah pandemi."

Sakdiyah: "Indonesia, Indonesia maju di tengah pademi yang jelas. ..."

Konteks tuturan pada data 3, yaitu Rosi memberikan kesempatan kepada Sakdiyah untuk menyampaikan harapannya pada bangsa Indonesia, yang menjelang kemerdekaannya ke tujuh puluh lima tahun. Tuturan Rosi dilakukan dengan cara memberikan kalimat pertanyaan "Apa materi stand up mu tujuh puluh lima tahun Indonesia merdeka?". Kata apa sebagai pronomina introgativa yang digunakan untuk menanyakan suatu perihal, dan dapat diposisikan di awal, tengah, dan belakang kalimat. Tuturan ini menghendaki agar Sakdiyah memberikan sebuah pernyataan tentang materi stand up yang akan dibahas pada kemerdakaan Indonesia ke tujuh puluh lima tahun. Pernyataan Rosi tersebut memiliki relevansi, karena latar belakang Sakdiyah sebagai seorang komika. Kemudian, Sakdiyah mengungkapkan bahwa materi yang akan diprensentasikan adalah Indonesia maju di tengah pandemi. Hal ini dapat dibuktikan pada pernyataan "Indonesia, Indonesia maju di tengah pademi yang jelas". Berdasarkan hal tersebut, dapat disimpulkan bahwa tuturan tersebut dapat dikategorikan sebagai maksim relevansi, karena tuturan memberikan kontribusi atau memiliki kesinambungan dengan apa yang dikehendai oleh mitra tutur.

\section{Ciri-ciri Linguistik pada Ragam Bahasa Formal dalam Dialog Rosi di Kompas TV}

Berdasarkan hasil analisis data, tuturan yang digunakan dalam diaolog Rosi menggunakan ragam bahasa formal. Indikator penggunaan ragam bahasa formal tersebut, dapat dilihat berdasarkan (1) penggunaan gramatikal yang eksplesit dan konsisten, (2) kelengkapan imbuhan, (3) pemakaian kata ganti resmi, (4) menggunakan kata baku dan menghindari unsur kedaerahan. Hal ini dapat dijelaskan sebagai berikut.

\section{Penggunaan Gramatikal yang Eksplesit dan Konsisten \\ Tuturan pewara (Rosi)} diwujudkan dengan menggunakan kalimat gramatikal. Kalimat gramatikal tersebut tersusun atas unsur-unsur yang sesuai dengan kaidah tata bahasa yang berlaku. Artinya, penggunaan kata, frasa, dan klausa dibentuk secara berurutan, sehingga makna yang disampaikan jelas dan dapat dipahami. Hal ini dapat dilihat berdasarkan fungsi gramatikal dalam kalimat tersusun secara tersistematis. Dapat dibuktikan pada data berikut.

(4) Dialog menit 1;30-2;06

Rosi: Empat Agustus lalu, Presiden Jokowi menandatangani Inpres nomor enam tahun dua ribuh dua

BASASTRA Jurnal Bahasa, Sastra, dan Pengajarannya

Volume 9 Nomor 2, Oktober 2021, P-ISSN 2302-6405, E-ISSN 2714-9765 
puluh tentang peningkatan disiplin dan penegakan hukum protokol kesehatan dalam pencegahan dan pengendalian covid-19. Disiplin dan penegakan hukum menjadi kata kunci. Mengapa? Apakah bangsa ini memang begitu lemah dalam disiplin untuk sehat bersama? sudah bergabung dengan saya viazoom menteri koordinator bidang pembangunan manusia dan kebudayaan Bapak Muhajir Effendi. Selamat malam Pak Muhajir.

Konteks tuturan pada data 4, yaitu Rosi menyampaikan informasi terkait apa yang sudah disampaikan oleh Presiden Republik Indonesia, dan menyapa narasumber Muhajir Efendi. Tuturan yang disampaikan Rosi menunjukkan bahwa penggunaan gramatikal dalam bahasa Indonesia sudah sesuai. Hal tersebut dapat dilihat berdasarkan pola fungsi kalimat pada pernyataan berikut. "Empat Agustus lalu (keterangan waktu) + Presiden Jokowi (subjek) + menandatangani (predikat) + inpres nomor enam tahun dua ribu dua puluh (objek/frasa nomina) + tentang peningkatan disiplin dan penegakan hukum protokol kesehatan dalam pencegahan dan pengendalian covid19 (pelengkap)". Kemudian pada pernyataan selanjutnya yaitu, "Disiplin dan penegakan hukum (subjek/frasa nomina) + menjadi (predikat) + kata kunci (pelengkap)". Kedua kalimat pada tuturan tersebut sudah memenuhi syarat sebuah kalimat, yaitu memiliki subjek dan predikat. Selain itu, penyusunan pola kalimat dilakukan secara tersistematis, sehingga memiliki makna yang jelas. Oleh karena itu, adanya pematuhan terhadap gramatikal, maka tuturan dapat dikategorikan sebagai ragam bahasa formal.

\section{Penggunaan Imbuhan yang Lengkap} Imbuhan dalam bahasa Indonesia lazim dikenal sebagai afiksasi. Pada ragam bahasa formal penutur ditutut untuk menggunakan imbuhan yang lengkap. Hal tersebut digambarkan pada tuturan pewara, yang menggunakan imbuhan lengkap untuk mendukung informasi yang disampaikan kepada narasumber. Dapat dilihat pada pernyataan berikut.

(5) Dialog menit 5;23-5;53

Rosi: "yang penting sehat bu Risma. Ibu saya mau langsung ke pertanyaan yang banyak sekali, menjadi pertanyaan publik yaitu hari Senin lalu. Ketika ibu bertemu dengan para dokter ibu langsung bersimpuh begitu. Minta maaf, banyak yang mengatakan ooo minta maaf karena tidak mampu mengelola Surabaya ada yang begini. Saya mau langsung dengar jawaban dari Bu Risma. Kenapa, apa yang 
terjadi dan mengapa harus bersimpuh?"

Konteks tuturan pada data 5, yaitu Rosi melakukan pengecekan atau mengonfirmasi tentang kejadian sujud yang dilakukan Risma. Tuturan yang dilakukan oleh Rosi diwujudkan dengan kalimat pertanyaan pada ragam bahasa formal.

Tuturan Rosi di atas dapat dikategorikan sebagai ragam bahasa formal, karena ditandai dengan penggunaan imbuhan yang lengkap. Afiksasi tersebut direalisasikan dengan beberapa kategori, yaitu sebagai berikut. (1) Kategori konfiks, pada kata pertanyaan (terdiri dari morfem dasar tanya dan morfem afiks pe-an). (2) Kategori prefiks, seperti pada kata sekali (terdiri dari morfem afiks $s e$-, dan morfem dasar kali), kata menjadi (terdiri dari morfem afiks men-, dan morfem dasar jadi), kata bertemu (terdiri dari morfem afiks ber-, dan morfem terikat temu), kata bersimpuh (terdiri dari morfem afiks ber- dan morfem dasar simpuh), kata mengelola (terdiri dari morfem afiks me- dan morfem dasar kelola), kata terjadi (terdiri dari morfem afiks ter- dan morfem dasar jadi), kata mengapa (terdiri dari morfem afiks meng- dan morfem dasar apa). (3) Kategori berklofik, pada kata mengatakan (terdiri dari morfem afiks me-kan dan morfem dasar kata). (4) Kategori sufiks, pada kata jawaban (terdiri dari morfem dasar jawab dan morfem afiks -an). Penggunaan imbuhan pada tuturan tersebut dilakukan dengan lengkap, sesuai dengan kaidah pada ragam bahasa formal.

\section{Penggunaan Kata Ganti Resmi}

Tuturan pewara dan narasumber dalam dialog Rosi menggunakan kata ganti resmi. Kata ganti resmi tersebut digunakan karena konteks kegiatan komunikasi bersifat resmi. Selain itu, sebagai representasi sikap sopan santun, mengingat latar belakang peserta tutur yang beranekaragam. Oleh karena itu, untuk menghindari terjadinya kesenjangan komunikasi antara pewara dan narasumber, maka penggunaan kata ganti resmi tersebut sangat penting untuk direalisasikan. Penggunaan kata ganti resmi dapat dilihat berdasarkan pernyataan berikut.

(6) Dialog menit 19;29-19;54

Risma: "IDI tidak nyampaikan begitu, karena IDI tahu, karena kita membuat prehospital juga yang seperti rumah sakit atlet itu. Kita di asrama haji, kami membuat yang sama untuk itu, dan sekarang pasien lebih dari empat ratus disitu."

Rosi: "maksud saya. Kenapa Ibu enggak langsung jawab saja dengan fakta lo, kami bisa bantu masih ada bad yang tersedia."

Risma: "sudah saya jelaskan, sudah saya jelaskan."

(7) Dialog menit 51;41-52;18

BASASTRA Jurnal Bahasa, Sastra, dan Pengajarannya

Volume 9 Nomor 2, Oktober 2021, P-ISSN 2302-6405, E-ISSN 2714-9765 
Rosi: "malam hari ini Rosi berbicara tentang ada apa dengan Risma? karena selama sepekan aksi Risma itu menjadi perbincangan, sujud di hadapan para dokter tenaga medis ketika berbicara soal penanganan covid 19. Apa yang sedang terjadi di kota Surabaya? Bagaimana sesungguhnya pola komunikasi koordinasi antara pemerintah kota Surabaya dengan pemerintah provinsi Jawa Timur dalam menangani Corona? untuk membahas ini saya mengundang pengajar di departemen komunikasi Fisip Unair. Selamat malam Pak Suko Widodo."

Suko Widodo: "selamat malam Mbak Rosi."

Konteks tuturan pada data 6, yaitu Risma memberikan penjelasan kepada Rosi tentang kejadian sebenarnya bahwa yang mengkritik dirinya bukan dari Ikatan Dokter Indonesia. Sementara, konteks pada data 7, yaitu Rosi memperkenalkan tema pembicaraannya, dan menyambut kehadiran narasumber yaitu Suko Widodo.

Berdasarkan data di atas, tuturan Risma dan Rosi menunjukkan penggunaan kata ganti yang resmi. Penggunaan kata ganti pada tuturan tersebut diwujudkan dengan beberapa kategori, yaitu sebagai berikut. (1) Pronomina persona, seperti kita, kami, dan saya. Penggunaan kata ganti tersebut memiliki fungsi yang berbeda. Pada pronomina kita dan kami digunakan untuk orang pertama jamak yang berfungsi menunjukkan rasa hormat dan digunakan untuk lawan bicara. Sementara pronomina saya digunakan untuk orang pertama tunggal oleh penutur siapa saja, tanpa memandang tingkatan umur dan profesi. Maka, Rosi dan Risma menggunakan pronomina saya, karena konteks komunikasi dilakukan secara formal. (2) Pronomina demontrativa, seperti itu, dan ini. Kata ganti itu digunakan untuk menunjukkan suatu benda/perihal yang jauh. Adapun kata ganti ini, untuk menyatakan benda/perihal yang lebih dekat. (3) Pronomina introgativa, seperti kenapa, apa, dan bagaimana. Kata ganti kenapa digunakan Rosi untuk menanyakan kepada Risma perihal alasan Risma yang tidak menjelaskan secara langsung bantuan yang sudah disediakan, sehingga tidak terjadi konflik dengan tenaga medis (dokter). Selanjutnya, kata ganti apa digunakan Rosi untuk menanyakan tentang peristiwa di kota Surabaya. Sementara, kata ganti bagaimana digunakan untuk menanyakan keadaan sebenarnya tentang situasi komunikasi dan kerja sama antara pemerintah kota Surabaya dengan pemerintah provinsi Jawa Timur. Hal tersebut dapat dilihat pada kutipan "Bagaimana sesungguhnya pola komunikasi koordinasi antara pemerintah kota Surabaya dengan 
pemerintah provinsi Jawa Timur dalam menangani Corona?". Dengan demikian, pada konteks komunikasi yang formal, peserta tutur dituntut untuk menggunakan pronomina resmi, agar tidak terjadi kesenjangan komunikasi.

\section{Penggunaan Kata Baku dan Menghindari Unsur Kedaerahaan}

Tuturan pewara pada ragam bahasa formal menggunakan kata yang baku. Penggunaan kata baku tersebut merujuk terhadap kesesuaian dalam Kamus Besar Bahasa Indonesia, serta menghindari pemakaian kata-kata yang bersifat kedaerahan. Hal ini dapat dilihat pada pernyataan berikut.

(8) Dialog menit 2;13-2;43

Rosi: "kita harus sehat, saling jaga. Pak Muhajir, Pak Jokowi minggu lalu kira-kira awal agustus mengeluarkan inpres yang tadi sudah saya sebutkan. Kata kuncinya adalah disiplin dan penegakan hukum. Situasi seperti apa sesungguhnya yang bisa kita lihat berbeda dengan keluarnya inpres ini? yang publik kemudian bisa percaya bahwa kita berada disituasi dimana ada pengurangan risiko penularan covid 19."

Konteks tuturan pada data, yaitu Rosi bertanya kepada Muhajir Efendi tentang kehadiran dan pengaruh adanya inpres bagi pelaksanaan protokol kesehatan.

Pada data, tuturan Rosi menggambarkan adanya penggunaan kosa kata yang sudah baku atau sesuai dengan kaidah bahasa Indonesia. Selain itu, di dalam tuturan tersebut tidak menunjukkan penggunaan bahasa daerah atau bahasa asing. Hal tersebut menjadi indikator bahwa tuturan tersebut sudah memenuhi syarat ragam bahasa formal. Latar belakang penggunaan ragam bahasa formal yang dilakukan oleh Rosi, karena situasi tutur berlangsung di acara televisi nasional yang menuntut penggunaan bahasa formal. Adapun faktor kawan tutur juga mempengaruhi penggunaan ragam bahasa formal. Dalam hal ini, kawan tutur yaitu Muhajir Efendi sebagai Mentri Pemberdayaan Manusia dan Kebudayaan, sehingga bahasa yang digunakan adalah bahasa formal. Ragam bahasa formal yang dilakukan oleh Rosi untuk menunjukkan rasa hormat kepada kawan tutur, dan menggambarkan kelas sosial.

\section{PEMBAHASAN}

Jenis-jenis Pemakaian Prinsip Kerja Sama pada Ragam Bahasa Formal dalam Dialog Rosi di Kompas TV

Berdasarkan hasil penelitian menunjukkan bahwa adanya pematuhan terhadap prinsip kerja sama (PK) dalam kegiatan dialog Rosi. Pematuhan terhadap prinsip kerja sama yang dilakukan oleh pewara dan

BASASTRA Jurnal Bahasa, Sastra, dan Pengajarannya

Volume 9 Nomor 2, Oktober 2021, P-ISSN 2302-6405, E-ISSN 2714-9765 
narasumber memberikan pengaruh yang positif terhadap iklim komunikasi. Artinya, dengan adanya maksim tersebut, maka dapat mengurangi terhadap terjadinya kesalahpahaman dalam kegiatan komunikasi. Hal tersebut sejalan dengan Rahardi (2005: 52), agar pesan dapat terealisasi dengan baik pada kegiatan berkomunikasi, maka peserta tutur harus memperhatikan prinsip kerja sama yang dikemukakan oleh Grice. Prinsip kerja sama (PK) merupakan suatu kaidah dalam berkomunikasi agar dapat berjalan efektif dan efisien, yang mampu meminimalkan kesalahpahaman yang dapat mengakibatkan terjadinya konflik (Hadiwijaya \& Amalyasari, 2019: 21). Dengan demikian, pematuhan terhadap prinsip kerja sama dalam konteks kegiatan komunikasi sangat esensial, agar kumunikasi berjalan secara efektif dan efesien.

Representasi pemakaian prinsip kerja sama pada ragam bahasa formal dalam dialog Rosi, dilakukan dengan tuturan yang bersifat informatif, memadai, berkontribusi, dan didukung oleh bukti yang kuat. Hal ini menjadi indikator bahwa antara penutur dengan kawan tutur sudah melakukan kerja sama, sehingga informasi yang disampaikan jelas dan dapat dipahami. Realisasi prinsip kerja sama tersebut sesuai dengan yang dikemukan Grice (dalam Maufur, 2016: 23), bahwa penutur hendaknya memberikan sumbangan informasi sesuai yang diinginkan pada saat melakukan komunikasi, dan berdasarkan tujuan/arah komunikasi yang sedang dilakukan. Artinya, setiap informasi yang disampaikan peserta tutur memiliki relevansi terhadap konteks percakapan.

Adapun untuk menguatkan hasil penelitian ini, maka peneliti membandingkan dengan penelitan yang sejalan oleh Kurniasih (2017), Ristiawan (2017), Sahara (2020), menunjukkan bahwa pematuhan terhadap prinsip kerja sama dilakukan dengan memenuhi syarat maksim relevansi, maksim pelaksanaan, maksim kuantitas, dan maksim kualitas. Adapun dalam penelitian ini, pematuhan terhadap prinsip kerja sama hanya ditemukan pada tataran maksim kuantitas, maksim kualitas, dan maksim relevansi. Sementara maksim cara/pelaksanaan banyak dilanggar oleh peserta tutur. Hal ini dapat terjadi, karena lazimnya kegiatan komunikasi pada sebuah acara talk show, peserta tutur banyak memberikan argumen yang panjang. Hal ini bertolak belakang dengan syarat maksim cara/pelaksanaan, yang menuntut agar tuturan bersifat ringkas, jelas, dan tersistematis.

Jenis-jenis prinsip kerja sama pada ragam bahasa formal yang diperoleh dari kanal youtube Kompas TV mengalami pengklasifikasian atas tiga ranah, yaitu; (1) maksim kuantitas, (2) maksim kualitas, dan (3) maksim relevansi. Pemakaian maksim tersebut 
diwujudkan dengan menggunakan kalimat tanya pada tataran sintaksis, karena konteks pembicaraan pada dialog. Oleh karena itu, strategi tuturan pewara berupa kalimat pertanyaan yang dikemukakan kepada narasumber.

Pertama, pada tataran maksim kuantitas menggunakan frasa nomina untuk menyampaikan informasi berupa pertanyaan kepada mitra tutur. Tuturan yang dilakukan pada maksim kualitas ini, yaitu memberikan informasi yang memadai, membuat penyataan seinformatif mungkin, dan memberikan kontribusi yang sesuai dengan dibutuhkan dalam kegiatan percakapan (Astriani, 2018: 36). Hal tersebut sejalan dengan penelitian ini, penutur dan mitra tutur memberikan kontribusi yang informatif dan memadai. Oleh karena itu, tuturan sudah memenuhi kaidah dalam maksim kuantitas. Meskipun tuturan peserta tutur dilakukan secara informatif, tetapi tetap menunjukkan nilai-nilai humanisme, dapat dilihat pada pernyataan "bagaimana kabarnya bu?". Tuturan tersebut mencerminkan adanya rasa peduli pewara terhadap narasumber.

Kedua, pada tataran maksim kualitas menggunakan kalimat tanya untuk membuktikan suatu kebenaran informasi. Kebenaran (fakta) dalam maksim kualitas sangat esensial agar tidak melanggar kaidah maksim tersebut. Lebih lanjut, (Rokhman \& Surahmat, 2020: 169) mengemukakan bahwa syarat dalam maksim kualitas, yaitu penutur memberikan informasi yang sesuai fakta dan didukung dengan bukti-bukti yang kuat. Pematuhan terhadap maksim kualitas, juga tercerminkan dalam penelitian ini, yaitu penutur memberikan pernyataan kepada kawan tutur dengan didukung bukti berupa inpres/pernyataan presiden sebagai rambu-rambu dalam imbauan protokol kesehatan. Adanya pematuhan terhadap maksim tersebut, maka kebenaran informasi dapat dipertanggungjawabkan dan menghindari informasi yang bersifat hoaks.

Ketiga, pada tataran maksim relevansi menggunakan kalimat pertanyaan untuk meminta argumentasi narasumber perihal konteks yang diperbincangkan. Dalam ranah maksim ini, penutur dituntut untuk menyampaikan tuturan yang memiliki kesinambungan terhadap kebutuhan informasi mitra tutur (Hudiyono, 2021: 5). Hal tersebut sesuai dengan hasil penelitian yang diperoleh, yakni penutur menyampaikan informasi kepada kawan tutur yang memiliki relevansi. Sehingga tuturan mematuhi terhadap kaidah maksim relevansi.

\section{Ciri-ciri Linguistik pada Ragam Bahasa Formal dalam Dialog Rosi di Kompas TV}

Sesuai dengan hasil penelitian yang diperoleh, tuturan yang dilakukan oleh pewara dan narasumber menggunakan ragam bahasa formal. Penggunaan ragam bahasa formal yang dilakukan oleh pewara dan narasumber dipengaruhi beberapa aspek, yaitu (1)

BASASTRA Jurnal Bahasa, Sastra, dan Pengajarannya 
peristiwa tuturan dilakukan pada acara televisi nasional, (2) latar belakang narasumber, dan (3) topik yang dibahas dalam kegiatan dialog. Hal tersebut sejalan dengan (Laba \& Rinayanthi, 2018: 21), mengatakan bahwa faktor munculnya ragam bahasa dipengaruhi oleh topik yang dibicarakan, latar belakang peserta tutur, media bahasa yang digunakan, dan situasi tuturan yang sedang dibicarakan. Selain empat faktor tersebut, aspek fungsi bahasa juga mempengaruhi terhadap penggunaan ragam bahasa (Holmes \& Wilson, 2017: 9). Dengan demikian, pemakaian ragam bahasa dalam kegiatan komunikasi memiliki koherensi dengan aspek sosial peserta tutur.

Adapun tolak ukur pemakaian ragam bahasa formal pada dialog Rosi yang didapat dari kanal youtube Kompas TV, yaitu penggunaan tuturan yang memenuhi ciri linguistik ragam bahasa formal, yaitu (1) menggunakan gramatikal secara eksplisit dan konsisten, (2) menggunakan imbuhan lengkap, (3) menggunakan kata ganti resmi, (4) menggunakan kata baku, (5) menggunakan PUEBI, dan (6) menghindari unsur kedaerahan (Eriyanti et al., 2020: 132), (Saputra, 2020: 60). Tetapi, pada penelitian ini juga ditemukan penggunaan istilah asing/daerah, seperti kata oke, sorry, prehospital, clear, epicentrum, moggo, dan lain sebagainya. Hal ini dapat terjadi, karena peserta tutur sulit mencari padanannya dalam bahasa Indonesia. Selain itu, faktor kebiasaan juga menjadi penyebab adanya kemunculan istilah asing/daerah pada tuturan tersebut. Pemakain istilah asing/daerah dalam dialog Rosi tidak banyak terjadi. Oleh karena itu, tuturan tetap dapat dikategorikan memenuhi syarat pada ragam bahasa formal.

Hasil penelitian ini dapat diperkuat dengan cara membandingkan dengan penelitian yang memiliki relevansi, yaitu sebagai berikut. Penelitian oleh (Handika et al., 2019), dengan hasil yang menunjukkan penggunaan ragam bahasa formal terjadi dalam interaksi pembelajaran di kelas, dengan cara dilihat berdasarkan kesesuaiannya dengan EYD. Selanjutnya penelitian yang dilakukan (Hidayat et al., 2018), menunjukkan penggunaan ragam bahasa formal dalam konteks acara talk show, dilihat berdasarkan pemenuhan terhadap syarat kelengkapan penggunaan imbuhan. Dari hasil penelitian tersebut, dapat disimpulkan bahwa pemakaian ragam bahasa formal baik dalam konteks pembelajaran di kelas maupun acara talk show dapat ditinjau bedasarkan ciri-ciri linguistik. Adapun di dalam penelitian ini, data yang ditemukan juga mencangkup ciri linguistik yang lain, sebagai mana yang dijelaskan di atas. Hal tersebut diuraikan sebagai berikut.

Pertama, penggunaan gramatikal yang eksplisit dan konsisten. Untuk membentuk kalimat gramatikal yang baik, maka kalimat disusun dengan berorientasi terhadap 
kaidah tata bahasa yang berlaku (Setiawati et al., 2017: 103). Dalam hal ini, hasil penelitian memenuhi terhadap aspek fungsi kalimat yang gramatikal. Artinya, pola penyusunan fungsi kalimat pada tuturan dialog Rosi tersusun secara tersistematis, seperti pada kalimat pertama memiliki pola $(\mathrm{Ket}+\mathrm{S}+\mathrm{P}+\mathrm{O}+\mathrm{Pel})$. Kemudian pada kalimat dua memiliki pola $(\mathrm{S}+\mathrm{P}+\mathrm{Pel})$. Dengan pola yang tersistematis, maka makna tuturan penutur mudah dipahami oleh kawan tutur.

Kedua, menggunakan imbuhan yang lengkap. Imbuhan pada ragam bahasa resmi meliputi prefiks, infiks, sufiks, konfiks, dan berklofiks (Chaer, 2008: 23-24). Tetapi, penggunaan imbuhan yang ditemukan dalam penelitian ini yaitu pada kategori prefiks, sufiks, konfiks, dan berklofiks. Hal ini karena penggunaan imbuhan infiks dalam bahasa Indonesia pemakaiannya terbatas pada kata-kata tertentu. Penggunaan imbuhan dalam kegiatan komunikasi memiliki kompleksitas tinggi, dan mempengaruhi terhadap makna kata yang diucapkan. Oleh karena itu, peserta tutur harus memperhatikan kelengkapan penggunaannya, agar memenuhi kaidah bahasa Indonesia. Representasi pemakaian imbuhan yang lengkap ditunjukkan dalam penelitian ini. Artinya, peserta tutur menggunakan imbuhan dengan lengkap, seperti me-kan, ber-, me-, dan lain sebagainya.

Ketiga, menggunakan kata ganti resmi. Pada ragam bahasa formal, kata ganti yang digunakan untuk menggantikan sebuah nomina/perihal harus disesuaikan dengan kaidah dalam bahasa Indonesia, seperti saya, kami, dan lain sebagainya. Pemakaian kata ganti pada sebuah tuturan, dapat dikelompokkan menjadi pronomina persona, pronomina demontrativa, pronomina introgativa, dan pronomina tak tentu (Chaer, 2008: 87). Sejalan dengan penelitian ini, pemakaian pronomina yang digunakan peserta tutur dalam dialog Rosi, pada ranah kata ganti diri, kata ganti tanya, dan kata ganti penunjuk. Pemakaian kata ganti yang resmi dalam dialog Rosi, bertujuan untuk saling menghormati antara penutur dan mitra tutur, dan menjalin komunikasi yang harmonis (sopan santun).

Keempat, menggunakan kata baku dan menghindari unsur kedaerahan. Pemakaian kata baku pada konteks tuturan yang resmi mengacu terhadap Kamus Besar Bahasa Indonesia, serta menghindari pemakaian kata-kata yang bersifat kedaerahan (Prihantini, 2015: 8). Disamping itu, penggunaan kalimat dalam ragam bahasa formal diharuskan untuk mengikuti Pedoman Umum Ejaan Bahasa Indonesia (PUEBI). Dalam hal ini, penemuan pada penelitian menunjukkan sudah memenuhi syarat tersebut. Artinya, pewara memiliki kesadaran atas konteks kegiatan tuturan, sehingga pemilihan diksinya mengarah kepada kata-kata yang baku. 
Jadi, berdasarkan uraian di atas dan membandingkan dengan penelitian terdahulu. Dapat disimpulkan bahwa ragam bahasa formal sangat esensial untuk diterapkan dalam kegiatan komunikasi, karena mempersentasikan intelektual/wibawa pengguna bahasa tersebut. Selain itu, karakteristik ragam bahasa formal dengan ragam bahasa lain, yaitu dapat ditinjau dari aspek ciri-ciri linguistik.

\section{SIMPULAN}

Jenis-jenis pemakaian prinsip kerja sama pada ragam bahasa formal yang telah ditemukan dalam penelitian ini, mencangkup maksim kuantitas, maksim kualitas, dan maksim relevansi. Jenis-jenis maksim tersebut merupakan hasil analisis terhadap kegiatan tuturan yang dilakukan dalam acara talk show. Dalam hal ini, tuturan yang diungkapkan oleh peserta tutur dengan cara memberikan sumbangan informasi yang informatif, memadai, didukung dengan bukti yang kuat, dan memiliki kontribusi sesuai konteks kegiatan komunikasi. Adanya pematuhan terhadap maksim tersebut, maka kegiatan komunikasi dapat berjalan secara efektif dan efesien. Selain itu, tuturan juga memberikan dampak positif terhadap terealisasinya nilai humanisme dan mengurangi berita hoaks.

Lebih lanjut, ciri-ciri linguistik ragam bahasa formal yang ditemukan dalam penelitian dicerminkan dengan memenuhi kaidah meliputi penggunaan gramatikal yang eksplisit dan konsisten, penggunaan imbuhan yang lengkap, penggunaan kata ganti resmi, dan penggunaan kata baku dan menghindari unsur kedaerahan. Hal tersebut terjadi, karena peristiwa tuturan dilakukan pada acara televisi nasional, latar belakang narasumber, dan topik yang dibahas dalam kegiatan dialog. Selain itu, tingkat pemakaian ragam bahasa formal setiap narasumber yang hadir berbeda-beda, baik dilihat berdasarkan penguasaan diksi maupun keruntutan kalimat. Oleh karena itu, dapat ditarik kesimpulan bahwa faktor sosial mempengaruhi terhadap penggunaan bahasa, salah satunya pada ragam bahasa formal.

Secara keseluruhan penelitian dapat disimpulkan bahwa pemakaian prinsip kerja sama memiliki relevansi dengan ragam bahasa formal. Artinya, kegiatan tuturan yang memenuhi kaidah ragam bahasa formal, maka menuntut peserta tutur memberikan informasi yang informatif, tersistematis, berkontribusi, dan jelas maknanya. Hal tersebut sesuai dengan syarat pada prinsip kerja sama. Adapun pemakaian prinsip kerja sama pada ragam bahasa formal sangat esensial untuk mewujudkan komunikasi yang baik, dan melestarikan bahasa formal yang sesuai dengan kaidah-kaidah dalam bahasa Indonesia.

\section{REFERENSI}

Anggito, A., \& Setiawan, J. (2018). Metodologi penelitian kualitatif. Jawa Barat: CV Jejak.

Astriani, A. S. (2018). Pelanggaran Prinsip Kerja sama dalam Acara 
Aiman dan Prabowo. Stilistika: Jurnal Pendidikan Bahasa dan Sastra, 11(1), 35-45.

Chaer, A. (2008). Morfologi Bahasa Indonesia: Pendekatan Proses. Jakarta: PT Reneka Cipta.

Eriyanti, R. W., Syarifuddin, K. T., Datoh, K., \& Yuliana, E. (2020). Linguistik Umum. Ponorogo: Uwais Inspirasi Indonesia.

Grice, P. (1989). Studies in the Way of Words. Cambridge: Harvard University Press.

Hadiwijaya, M., \& Amalyasari, M. R. (2019). Implementasi Prinsip Kerjasama Mahasiswa Multikultural di Kota Malang. KEMBARA: Jurnal Keilmuan Bahasa, Sastra, dan Pengajarannya, 5(2), 219-230.

Handika, K. D., Sudarma, I. K., \& Murda, I. N. (2019). Analisis Penggunaan Ragam Bahasa Indonesia Siswa dalam Komunikasi Verbal. Jurnal Pedagogi dan Pembelajaran, 2(3), 358-368.

Herisetyanti, T., Suharyati, H., \& Rejeki, S. (2019). Ragam Bahasa dalam Komponen Tutur. Media Bahasa, Sastra, dan Budaya Wahana, 25(2), 1-15.

Hidayat, M., Rusminto, N. E., \& Widodo, M. (2018). Ragam Bahasa dalam Acara Talk Show Mata Najwa Periode Januari 2017 dan Implikasinya dalam Pembelajaran Bahasa Indonesia di SMA. Jurnal Kata (Bahasa, Sastra, dan Pembelajarannya), 6(2), 1-8.

Holmes, J., \& Wilson, N. (2017). An Introduction to Sociolinguistics. London dan New York: Taylor \& Francis.

Hudiyono, Y. (2021). Wacana
Percakapan Instruksional: Kajian Struktur, Strategi, dan Fungsi. Yogyakarta: CV Istana Agency.

Kurniasih, E. (2017). Realisasi Prinsip Kerja Sama dalam Percakapan Masyarakat Sedulur Sikep Pati. Deiksis: Jurnal Pendidikan Bahasa dan Sastra Indonesia, 9(2), 109-118.

Kushartanti. (2005). Pesona bahasa: Langkah Awal Memahami Linguistik. Jakarta: Gramedia Pustaka Utama.

Laba, I. N., \& Rinayanthi, N. M. (2018). Buku Ajar Bahasa Indonesia Berbasis Karya Tulis Ilmiah. Yogyakarta: Deepublish.

Maufur, S. (2016). Penerapan Prinsip Kerja Sama dan Prinsip Sopan Santun Berbahasa di Kalangan Masyarakat Kampung Pesisir Kota Crebo. Al Ibtida, 3(1), 1838.

Mujiyati. (2017). Penggunaan Bahasa dalam Bimbingan dan Konseling. Jurnal Fokus Konseling, 3(2), 114-122.

Prasasti, B. W. D., \& Mujianto, G. (2020). Pemakaian Akrolek pada Tuturan Asertif dalam Gelar Wicara Hitam Putih. Jurnalistrendi : Jurnal Linguistik, Sastra, dan Pendidikan, 5(2), 147-164.

Prihantini, A. (2015). Master Bahasa Indonesia: Panduan Tata Bahasa Indonesia Terlengkap. Yogyakarta: Bentang B first.

Rahardi, R. K. (2005). Pragmatik: Kesantunan Imperatif Bahasa Indonesia. Jakarta: Erlangga.

Ristiawan, H. (2017). Prinsip Kerja Sama dalam Berinteraksi di Lingkungan SMPN 11 Kota Jambi. Pena, 7(2), 99-116.

Rokhman, F., \& Surahmat. (2020). 
Linguistik Disruptif: Pendekatan Kekinian Memahami Perkembangan Bahasa. Jakarta Timur: Bumi Aksara.

Rudi, \& Mujianto, G. (2021). Tuturan

Ekspresif Pengajar BIPA dalam Pembelajaran Keterampilan Berbicara dengan Metode Dengar Pandang. Alinea: Jurnal Bahasa Sastra dan Pengajaran, 10(1), 67-84.

Rukin. (2019). Metodologi Penelitian Kualitatif. Sulawesi Selatan: Yayasan Ahmar Cendekia Indonesia.

Sahara, M. U. (2020). Prinsip Kerja Sama Grice pada Percakapan Film. BASINDO : Jurnal Kajian Bahasa, Sastra Indonesia, dan Pembelajarannya, 4(2), 222-231.

Saputra, R. R. (2020). Bahasa Indonesia. Yogyakarta: Deepublish.

Setiawati, E., Dewi, P. K., \& Budiana, N. (2017). Bahasa Indonesia Akademik: Pengembangan Kepribadian Berbasis Pendidikan Karakter. Malang: Universitas Brawijaya Press.

Suhendar, N. (2016). Ragam Bahasa di Kecamatan Pakisjaya Kabupaten Karawang (Kajian

Sosiolinguistik). Lokabahasa: Jurnal Kajian Bahasa, Sastra, Budaya Daerah serta Pengajarannya, 7(1), 53-61.

Sumarsono. (2017). Sosiolinguistik. Yogyakarta: Pustaka Pelajar.

Ula, M., Santoso, A. B., \& Winarsih, E. (2020). Penggunaan Bahasa Pembawa Acara Pernikahandi Wilayah Madiun. Widyabastra: Jurnal Ilmiah Pembelajaran Bahasa dan Sastra Indonesia, 8(1), 48-59.

Warni, D. (2019). Analisis Ragam
Bahasa Pesan Kesehatan di Klinik Pratama Siti Kholijah Hsb Medan Marelan. Universitas Muhammadiyah Sumatra Utara. Wijining, A. N. (2018). Penerapan prinsip kerjasama Grice dalam percakapan di persidangan agama Surabaya. Universitas Wijaya Kusuma Surabaya.

BASASTRA Jurnal Bahasa, Sastra, dan Pengajarannya

Volume 9 Nomor 2, Oktober 2021, P-ISSN 2302-6405, E-ISSN 2714-9765 